\title{
非侵襲的な脳内への薬物送達技術の開発と脳神経疾患治療への応用
}

\author{
金 沢 貴 憲†
}

\section{Development of Noninvasive Drug Delivery Systems to the Brain for the Treatment of Brain/Central Nervous System Diseases}

\author{
Takanori Kanazawa ${ }^{\dagger}$ \\ Laboratory of Pharmaceutical Technology, School of Pharmacy, Tokyo University of \\ Pharmacy and Life Sciences; 1432-1 Horinouchi, Hachioji, Tokyo 192-0392, Japan.
}

(Received July 31, 2017)

\begin{abstract}
In general, the blood-brain barrier (BBB) poses a major challenge to drug development efforts targeting brain/central nervous system (CNS) diseases, since it limits the distribution of systemically administered therapeutics to the brain/ CNS. Therefore, the development of effective strategies for enhancing drug delivery to the brain has been a topic of great interest in both the clinical and pharmaceutical fields. Intranasal administration has been noted as a method for noninvasive delivery of a drug to the brain/CNS by bypassing the BBB via the "nose-to-brain" route. This nose-to-brain delivery system has the potential to be highly versatile, and a combination of this system with new drugs and siRNA shows promise in the treatment of CNS diseases. Cell-penetrating Tat peptide-modified block copolymer micelles have the potential for improving mucosal permeability and nose-to-brain transport efficiency. In addition, nano-sized drug carriers can improve nose-to-brain delivery through their ability to increase the stability of encapsulated drugs against biological degradation in the nasal cavity and brain/CNS. In this review, we introduce the assessment of and mechanisms for delivery to the brain after intranasal drug/siRNA administration with our cell-penetrating peptide-modified nano-sized polymer micelles. Our findings show that the use of polymer micelles with surface modification by cellpenetrating peptides for intranasal administration enables the noninvasive delivery of therapeutic agents to the brain/ CNS by increasing the nose-to-brain transfer of the drug or siRNA administered from the nasal cavity.
\end{abstract}

Key words — nose-to-brain route; drug delivery system; polymer micelle; cell-penetrating peptide; siRNA delivery; brain/central nervous system disease

\section{はじめに}

アルツハイマー病, パーキンソン病, 脳血管障 害，脳腫瘍に代表される難治性の脳・中枢神経系 (central nervous system; CNS) 疾患は, その多く がアンメットメディカルニーズの高い疾患である. 現在行われている治療法として，薬物治療や外科的 手術があるものの，そのほとんどは，根治療法では なく, 症状の進行を阻止して QOL を高める治療法 となっている。 そのため, CNS 疾患に対して, 画 期的なメカ二ズムを有する新規の低分子治療薬や, タンパク質やペプチドといつたバイオ医薬，あるい

東京薬科大学薬学部製剤設計学教室（下192-0392 東京 都八王子市堀之内 1432-1)

現所属： ${ }^{\dagger}$ 日本大学薬学部薬剤学研究室（T274-8555

千葉県船橋市習志野台 7-7-1)

e-mail: kanazawa.takanori02@nihon-u.ac.jp

本総説は，平成 28 年度日本薬学会関東支部奨励賞の受

賞を記念して記述したものである.
は siRNA やアンチセンス核酸といつた核酸医薬の 開発に対して，新たな CNS 疾患治療薬として大き な期待が寄せられている。しかしながら，有効な治 療を達成するためには，新規治療薬の開発のみなら ず，疾患部位である CNS へ効率的にこれら治療薬 を届けるドラックデリバリーシステム（drug delivery system; DDS）を開発することが必要不可欠で ある。一般に，全身循環血流を介した脳への物質の 移行は，血管内皮細胞同士の密着結合，連続した基 底膜並びにその周囲に位置するアストロサイトの突 起により構成される血液脸関門（blood-brain barrier; BBB） の存在により, 電解質やグルコースと いつた一部の低分子化合物をのぞき，大きく制限さ れている. 1,2) そのため，経口投与や静脈内投与を介 した脳への薬物送達はほとんど見込めず，BBBの 存在が脳・中枢神経疾患治療の大きな障壁の 1 つと なっている。また， BBBを回避できる方法とし 


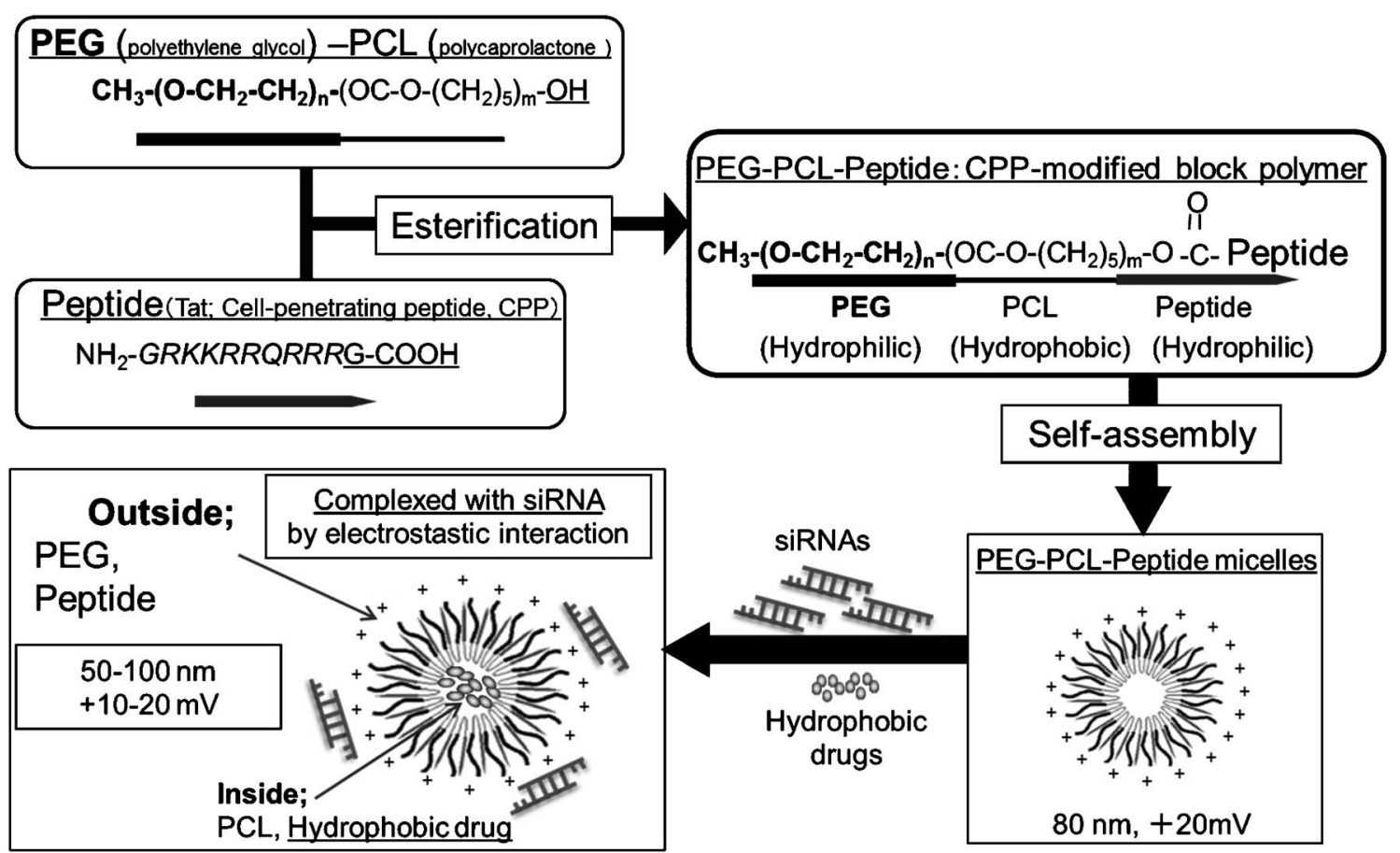

Fig. 1. Structure of Tat Peptide-modified PEG-PCL Micelle (PEG-PCL-Peptide)

Carboxylic group in cell-penetrating peptide Tat (Peptide) was conjugated to the hydroxyl group in PEG-PCL by esterification. PEG, polyethylene glycol; PCL, polycaprolactone.

て, 脳組織間隙に高濃度の薬物を直接送達できる脳 室内投与や麻酔などに用いられている髄腔内投与が 挙げられるものの，このような脳・髄腔への直接投 与は，侵襲性が高いため，頻回投与が必要な治療の 場合，患者への負担は大きい。そのため，非侵襲的 かつ効率的に CNS へ薬物を送達する新規 DDS の 開発が求められている.

近年，BBB を介さずに薬物を脳へ送り込む新た な手段として，鼻腔より鼻粘膜層を介して脳へ移行 する“Nose-to-Brain”経路が報告されている. ${ }^{3-6)}$ 経鼻投与された薬物は，その大部分は $\mathrm{BBB}$ を介さ ず，鼻腔内の嗅粘膜上皮組織に局在する嗅神経や呼 吸粘膜上皮組織に局在する三叉神経，あるいは脳脊 髄液（cerebrospinal fluid; CSF）などを介して脳へ 移行することが報告されている。. ${ }^{5,6)}$ また，経鼻投与 は，非侵襲的であるため患者自身による自己投与や 頻回投与が可能であることから，経口・静脈内投与 や直接脳内あるいは䯣腔内に投与する脳室内投与 ・ 髄腔内投与よりも有用性が高いと考えられ，近年で は，低分子化学療法剤を始め, ペプチドやタンパク などの脳・中枢神経系への送達手段として，数多く 検討されている.5)しかしながら，この“Nose-toBrain”経路には，鼻粘膜上皮層や粘液，さらには
繊毛クリアランスなどの物理的障壁が存在してい る。そのため，低分子薬物や核酸医薬の効率的な Nose-to-Brain デリバリーを達成するには，これら 障壁を突破させるための DDS キャリアの併用が必 要となる.

本稿では, 細胞透過性・粘膜透過性ペプチド修飾 ナノキャリアを基盤とした新規 Nose-to-Brain DDS による薬物・核酸医薬デリバリーについて，その脳 内への薬物移行性, Nose-to-Brain 促進機構並びに 疾患モデルによる治療効果を中心に概説する.

1. 細胞透過性ナノキャリアの開発と経鼻投与後 の脳への薬物 · 核酸医薬送達性7)

経鼻投与による脳への薬物送達効率を高めるに は，鼻粘膜上皮層における透過性を向上させる必要

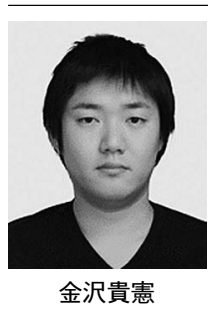

日本大学薬学部専任講師, 博士（薬 学). 東京薬科大学薬学部客員講師, 国 立がん研究センター機能診断開発分野 外来研究員 兼務. 2006 年東京薬科大 学大学院博士前期課程修了, 同大学助 手, 助教, 講師を経て, 2017 年 4 月よ り現職. 2013 年日本薬剂学会 Postdoctoral Presentation Award, 2016 年日本 薬学会関東支部奨励賞受賞など．専門 は, 薬剤学, DDS. 
があるＨIV-Tat タンパク質のアルギニンとリジ ンに富む塩基性ペプチド領域（YGRKKRRQRRR, Tatペプチド）は，負電荷の細胞膜表面と相互作用 し易く高い細胞膜透過性を示すことが知られてい る。この Tat ペプチドには，細胞膜透過性に加 え，細胞間の密着結合（タイトジャンクション）を 開口する作用もあるといわれており，安定性に優れ たナノキャリアに修飾することで粘膜上皮細胞間並 びに支持細胞間を介しての薬物移行促進作用を発揮 することが期待できる．また，経鼻投与後の粘膜に おける排泄機構に対して, 生体内安定性と薬物保持 能を有するキャリアが必要不可欠である，そこで筆 者は，親水性高分子であるポリエチレングリコール （polyethylene glycol; PEG）と疎水性コア領域を形 成するポリカプロラクトン（polycaprolactone; PCL）を連結させた，水中で自己会合することで, ナノサイズの安定性に優れたミセルを形成するブ ロック共重合体（PEG-PCL）を合成し，そこに Tat ペプチドを化学的に結合させた，Tat ペプチド 修飾ブロック共重合体 (PEG-PCL-Peptide, Fig. 1) を開発した。 ${ }^{8)}$ PEG-PCL-Peptide は，水中で疎水性 基（PCL）が内側に，親水性基（PEG，Tat ペプチ ド）が外側に配位することにより，表面電荷が正に 帯電した 50-60 nm のミセルを形成した (Table 1). また， 疎水性低分子の抗がん剂であるカンプトテシ ンを封入した結果, 約 $90 \%$ の高い封入効率を示し た。ささに，正電荷を有することから， siRNA（21 bp, MW: 13300) と混合することで, 静電的相互作 用により，約 $60 \mathrm{~nm}$ かつ正電荷を示すナノサイズ の複合体を形成した. ${ }^{9}$

次に, 疎水性の蛍光モデル物質であるクマリンを 封入した PEG-PCL-Peptide の経鼻投与後の体内分 布を検討した. ${ }^{10)}$ Figure 2(A)には，クマリン単独 及びクマリン封入 PEG-PCL-Peptide を脳腫瘍同所 移植ラットへ経鼻投与した際の脳を含めた体内分布 の結果を示す。いずれの群においても脳への高い分 布が示され，経鼻投与による Nose-to-Brain デリバ リーの有用性が示唆された。このとき, クマリン単 独投与群で脳への最も高い分布がみられたものの, 肺や腎臓などの末梢組織での分布も顕著に高くなつ た。一方，クマリン封入 PEG-PCL-Peptide 投与群 では，末梢組織への分布は，脳への分布と比較し， いずれも低かった。 また，クマリンを経鼻及び静脈
Table 1. Physicochemical Characterization of PEG-PCLPeptide, Camptothecin (CPT)-loaded PEG-PCL-Peptide, and siRNA-loaded PEG-PCL-Peptide Micelles

\begin{tabular}{c|c|c}
\hline \hline Polymer & $\begin{array}{c}\text { Mean diameter } \\
(\mathrm{nm})\end{array}$ & $\begin{array}{c}\text { Zeta potential } \\
(\mathrm{mV})\end{array}$ \\
\hline PEG-PCL-Peptide & $83.9 \pm 20.7$ & $20.3 \pm 2.98$ \\
\hline $\begin{array}{c}\text { CPT-loaded } \\
\text { PEG-PCL-Peptide }\end{array}$ & $125.8 \pm 7.76$ & $27.4 \pm 4.21$ \\
\hline $\begin{array}{c}\text { siRNA-loaded } \\
\text { PEG-PCL-Peptide }\end{array}$ & $64.0 \pm 14.0$ & $13.0 \pm 0.45$ \\
\hline
\end{tabular}

Each value represents the mean \pm S.D., $n=3$.

A) Coumarin (Hydrophobic low molecule)

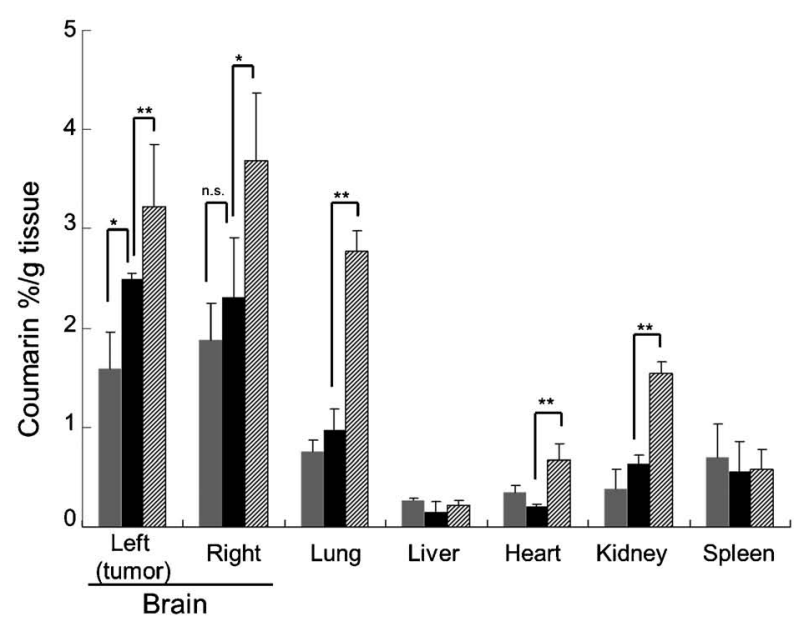

B) Fluorescein-model siRNAs

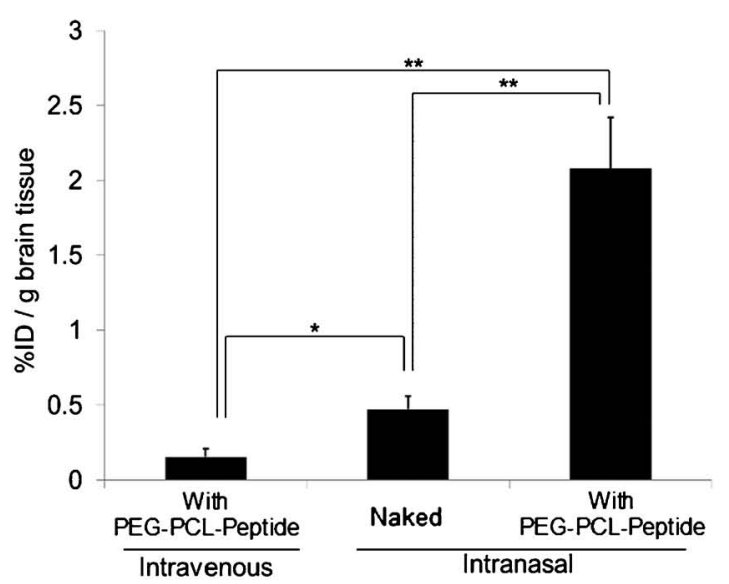

Fig. 2. Biodistribution of Coumarin or Brain Distribution of Fluorescein-model siRNAs in Rats

A) Rats were sacrificed at $1 \mathrm{~h}(\boldsymbol{)})$ or $4 \mathrm{~h}(\mathbf{C})$ after intranasal administration of coumarin-loaded PEG-PCL-Peptide micelles, or $1 \mathrm{~h}$ (שZZ) following the injection of coumarin solution (dose corresponding to $20 \mu \mathrm{g}$ of coumarin) . B) Rats were sacrificed at $1 \mathrm{~h}$ after intranasal or intravenous administration of naked fluorescein-model siRNAs (Naked) or with PEGPCL-Peptide (dose corresponding to $40 \mu \mathrm{g}$ of Fluorescein-model siRNAs), and each brain was enucleated. Each bar represents the mean \pm S.E. $(n=4)$. ${ }^{* *} p<0.01,{ }^{*} p<0.05$. 
A) Olfactory mucosa

Naked

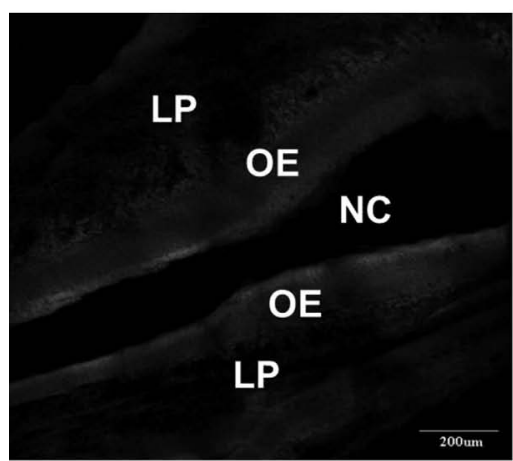

B) Trigeminal nerve
With PEG-PCL-Peptide

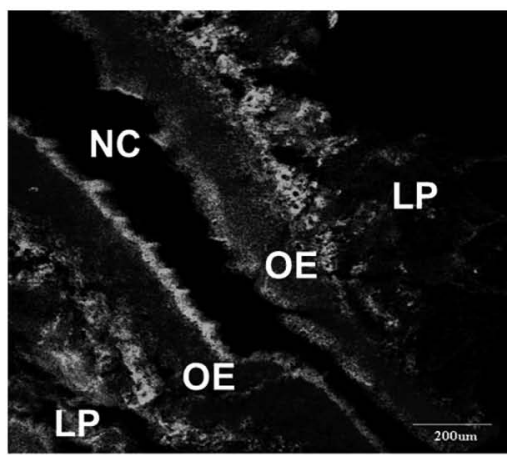

Naked
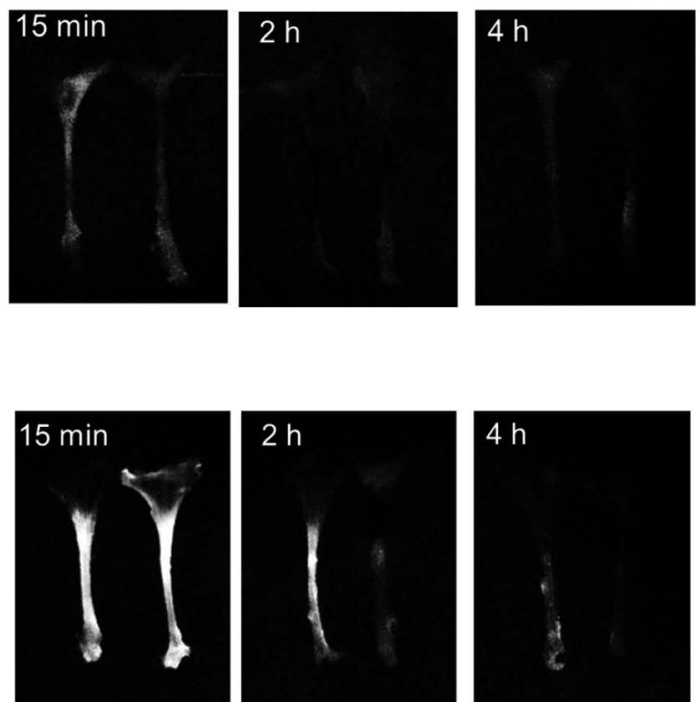

Fig. 3. Distribution of siRNAs in Olfactory Mucosa or Trigeminal Nerve in Rats

Rats were sacrificed at A) $15 \mathrm{~min}$, or B) $15 \mathrm{~min}, 2 \mathrm{~h}$ and $4 \mathrm{~h}$ after intranasal administration of naked siRNA (Naked) or with PEG-PCL-Peptide (dose corresponding to $40 \mu \mathrm{g}$ of siRNA). A) Olfactory mucosa was collected, and sliced to $16-\mu \mathrm{m}$ sections. White color represents Fluorescein (FAM) -labeled control siRNA. OE, olfactory mucosa epithelium; LP, lamina propria; NC, nasal cavity. Scale bar $=200 \mu$ m. B) Each trigeminal nerve was enucleated and observed using in vivo fluorescein imaging system $\left(\right.$ Maestro $\left.^{\mathrm{TM}}\right)$.

投与した際の血中濃度推移を測定したところ, 静脈 内投与では 48 時間まで高い血液濃度を示したのに 対し，経鼻投与群においては，クマリンを単独で投 与した場合には初期に血中濃度の上昇がみられるも のの, PEG-PCLナノキャリアに封入して投与した

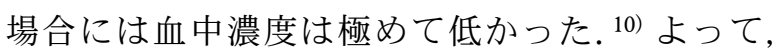
PEG-PCL ナノキャリアを経鼻投与と併用すること で，疎水性低分子薬の血中への移行や未梢組織への 分布を低下させたことから，全身性の副作用が危惧 される抗がん剂の CNS デリバリーへの応用が期待
できる.

さらに, 水溶性高分子である核酸医薬の Nose-toBrain デリバリーについて検討した. ${ }^{11)}$ Figure 2(B) に蛍光標識した水溶性高分子である Dextran （MW: 10000）をモデル siRNA として経鼻投与し た際の脳への移行性について，静脈投与と比較検討 した結果を示す．経鼻投与時の脳内移行性は，静脈 内投与時に比べ有意に高いことから, 経鼻投与の有 用性が示された。 さらに，PEG-PCL-Peptide を用 いて蛍光標識モデル siRNA を経鼻投与した群は, 
モデル siRNA 単独投与（Naked）群に比べ顕著に 高い脳内移行性を示した。

よって, PEG-PCL-Peptide ミセルは，疎水性低 分子薬だけでなく，水溶性高分子である siRNA の Nose-to-Brain デリバリーを向上させる優れた Nose-to-Brain DDS キャリアであることが示された.

2. PEG-PCL-Peptide ミセルによる Nose-toBrain 薬物移行促進機構 11 .

本項では，PEG-PCL-Peptide ミセルによる Nose-to-Brain デリバリーの促進機構を検討するた め，鼻腔から脳をつなぐ Nose-to-Brain 経路として 報告されている嗅神経経路並びに三叉神経経路に着 目した研究例を示す。一般に，嗅神経経路は鼻腔内 嗅粘膜組織に局在している嗅神経を介した薬物輸送 ルートであり, 脳の先端に位置する嗅球へと薬物が 運ばれ，三叉神経経路は，鼻腔内呼吸粘膜組織に局 在している三叉神経枝を介して延髄・後脳へと薬物 が運ばれることが報告されている.5,6)これら経路に 係わる嗅粘膜，三叉神経，CSF，並びに嗅球や延 髄・後脳といつた脳組織への siRNAの分布につい て検討した。

Figure 3(A) は，FAM で蛍光標識 siRNA（Control siRNA, 21 bp, MW: 13300）の経鼻投与 15 分後 の嗅粘膜組織中の分布を共焦点顕微鏡で観察した結 果である、結果より，PEG-PCL-Peptide を併用し ない単独（Naked）群では，粘膜上皮表面にの夕蛍 光が観察されるのに対して, PEG-PCL-Peptide を 併用した群では，嗅粘膜上皮表面だけでなく，粘膜 上皮下の粘膜固有層において強い蛍光が認められ た。これは, PEG-PCL-Peptide 併用による粘膜内 での安定性及び粘膜透過性の向上によるものと推察 される，嗅粘膜には嗅神経が存在し，その先には嗅 神経束, 篩板, 嗅球などの脳移行に重要な組織が続 いている，そのため, 脳への薬物送達量を増加させ るためには，PEG-PCL-Peptide ミセルのように粘 膜上皮の透過を促進する DDS キャリアが有用であ ることが示唆された. 次に, 蛍光標識モデル siRNA 経鼻投与後の三叉神経を in vivo 蛍光イメージング 装置を用いて経時的に観察した. Figure 3(B)より,

PEG-PCL-Peptide 併用群は，モデル siRNA 単独 (Naked) 群と比べ，三叉神経に強い蛍光が観察さ れた。これらの結果より, PEG-PCL-Peptide は嗅 神経経路と同様に，延髄・後脳につながる三叉神経

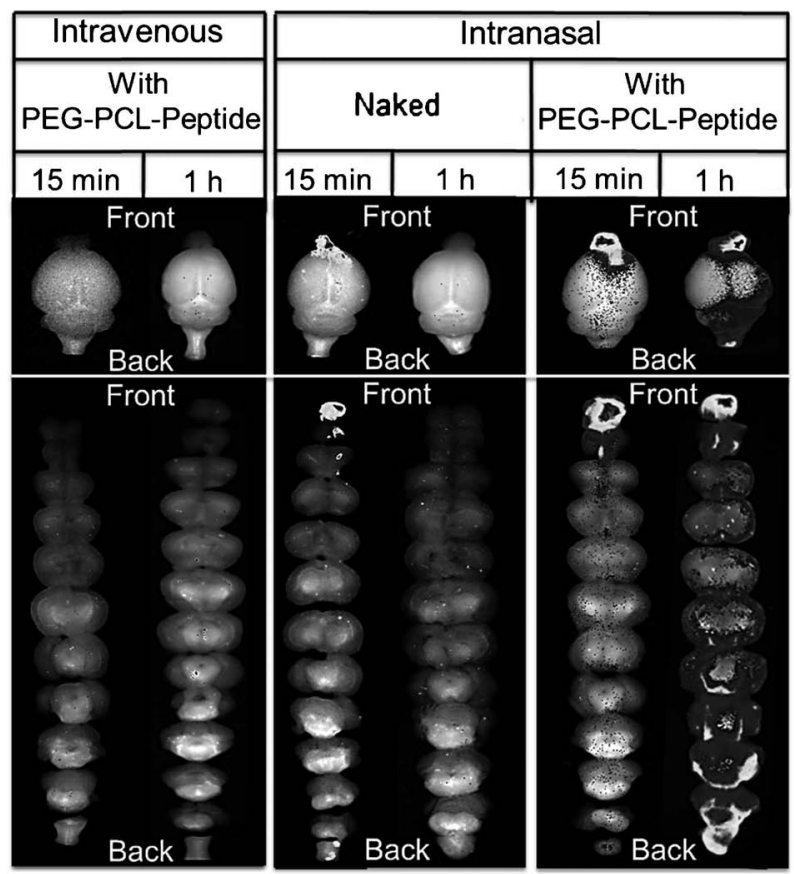

Fig. 4. Dynamics of siRNAs in Brain Tissue in Rats

Rats were sacrificed and brains were enucleated at each point after intranasal or intravenous administration of naked fluorescein-model siRNAs (Naked) or with PEG-PCL-Peptide (dose corresponding to $40 \mu \mathrm{g}$ of fluorescein-model siRNAs). Each sample was observed using in vivo fluorescein imaging system $\left(\right.$ Maestro $\left.^{\mathrm{TM}}\right)$.

経路への移行も促進することで siRNA を広範囲の 脳組織へ効果的に送達することが示唆された。ま た，経時的な CSF 濃度を測定した結果，PEGPCL-Peptide 併用群は, 単独群に比べ経鼻投与後の CSF 中の濃度が長時間有意に高く保たれていた。

一般に嗅神経経路や三叉神経経路を介して，嗅球や 延髄・後脳へ移行した薬物の一部は, 到達組織やそ の周辺組織から CSFへと移行することが知られて

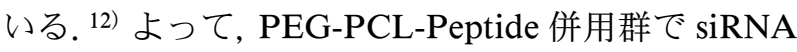
の CSF 中濃度が増加した理由として, 嗅神経経路 並びに三叉神経経路を介する脳組織への移行が向上 した結果, 到達先である各脳組織やその周辺組織中 の siRNA 濃度が増大したためであると推察される.

Figure 4 には，蛍光標識モデル siRNA を静脈内 投与又は経鼻投与し 15 分と 1 時間後の脳を蛍光个 メージング装置で観察した結果を示す。上段には, 脳を上から撮影した図を，下段には，2 mm 毎にス ライスした脳の断面図を示す．Figure 4 より，静脈 内投与したラットの脳において蛍光は全く観察され なかったのに対し，経鼻投与したラットの脳では蛍 光が観察された。特に, PEG-PCL-Peptide を併用 
A) Kaplan-Meier survival curves

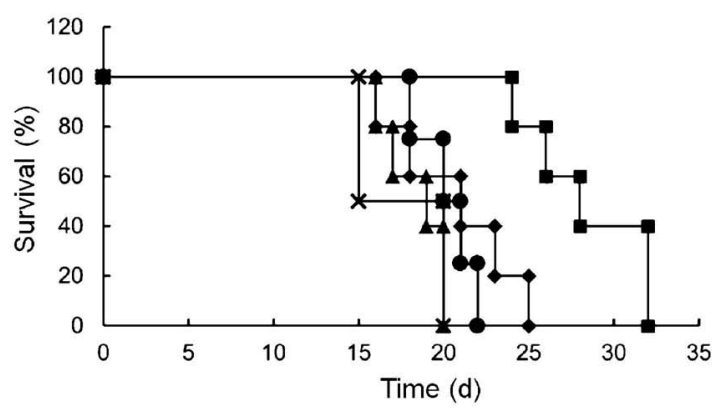

B) HE-stained brain tissue

Untreated

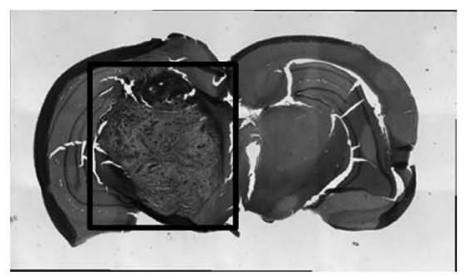

siRaf-1-loaded PEG-PCL-Peptide

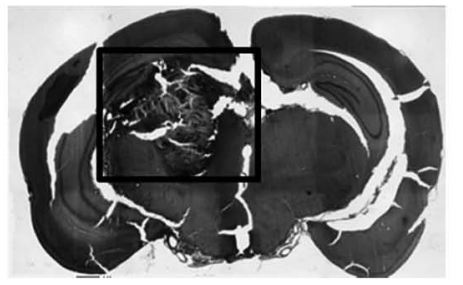

CPT/siRaf-1-loaded PEG-PCL-Peptide

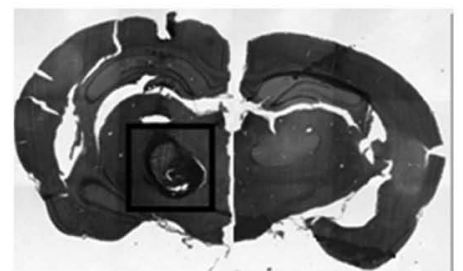

naked siRaf-1

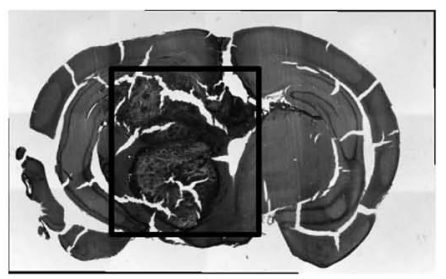

CPT/siControl-loaded PEG-PCL-Peptide

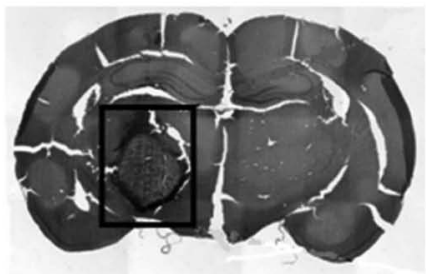

Fig. 5. Survival and HE-stained Brain Tissue in Intracranial C6 Glioma-bearing Rats

A) Kaplan-Meier survival curves of intracranial C6 glioma-bearing rats, untreated (cross) or treated with intranasal administration of naked siRaf-1 (triangle), siRaf-1-loaded PEG-PCL-Peptide (circle), camptothecin (CPT)/siControl-loaded PEG-PCL-Peptide (diamond) or CPT/siRaf-1-loaded PEG-PCL-Peptide (square) $(0.36 \mathrm{mg} / \mathrm{kg} \mathrm{CPT}, 0.1 \mathrm{mg} / \mathrm{kg}$ siRNA, $n=5)$. B) HE-stained brain tissue in intracranial C6 glioma-bearing untreated rats, or rats treated with intranasal administration of naked siRaf-1, siRaf-1-loaded PEG-PCL-Peptide, CPT/siControl-loaded PEG-PCL-Peptide, and CPT/siRaf-1-loaded PEG-PCL-Peptide. After two weeks, tissues were taken and sliced to $16 \mu \mathrm{m}$-sections. Each section was stained with HE, and observed using light optical microscopy.

した群において, 強い蛍光が広範囲に観察できた. さらにこのとき鼻から脳への代表的な移行経路であ る，脳の先端に位置する嗅球並びに脳の後方に位置 する脳幹に強い蛍光が観察された.

以上のことから，PEG-PCL-Peptide による鼻か ら脳への Nose-to-Brain デリバリーは，嗅神経経 路，三叉神経経路を介した脳・CSFへの移行を増 大させることが示された.

\section{3. 脳腫瘍同所移植ラットにおける PEG-PCL-} Peptide ミセルと Nose-to-Brain を用いた薬物・核 酸医薬デリバリーによる治療効果 ${ }^{10)}$

前項までの検討により，PEG-PCL-Peptide ミセ ルと Nose-to-Brain を併用することで，疎水性の低 分子薬物だけでなく, 水溶性高分子である核酸医薬 の siRNA をも CNS へ効率的に送達できることを 明らかとした。そこで，次に，PEG-PCL-Peptide 
Table 2. Median Survival Period of Rats Bearing Intracranial C6 Glioma Treated with Camptothecin (CPT)-loaded Micelles

\begin{tabular}{c|c|c|c}
\hline \hline Treatment & $\begin{array}{c}\text { Number } \\
\text { of rats }\end{array}$ & $\begin{array}{c}\text { Average of } \\
\text { survival period } \\
(\mathrm{d})\end{array}$ & $p$ value \\
\hline Untreated & 5 & 16.6 & \\
\hline Naked siRaf-1 & 5 & 18.4 & \\
\hline $\begin{array}{c}\text { siRaf-1-loaded } \\
\text { PEG-PCL-Peptide }\end{array}$ & 5 & 20.4 & $<0.05^{\mathrm{a}, \mathrm{b}}$ \\
\hline $\begin{array}{c}\text { CPT/siControl-loaded } \\
\text { PEG-PCL-Peptide }\end{array}$ & 5 & 20.6 & $<0.05^{\mathrm{a}, \mathrm{b}}$ \\
\hline $\begin{array}{c}\text { CPT/siRaf-1-loaded } \\
\text { PEG-PCL-Peptide }\end{array}$ & 5 & 28.4 & $<0.01^{\mathrm{a}, \mathrm{b}}$, \\
\hline
\end{tabular}

a Compared to untreated rats, ${ }^{b}$ Compared to naked siRaf-1, ${ }^{\mathrm{c}}$ Compared to siRaf-1-loaded PEG-PCL-Peptide, ${ }^{\mathrm{d}}$ Compared to CPT/siControl-loaded PEG-PCL-Peptide.

ミセルと Nose-to-Brain を併用した際の薬物・核酸 医薬によるCNS 疾患治療の可能性について検討す るため, 抗がん剤であるカンプトテシン及び抗アポ トーシス作用及び細胞増殖の促進を引き起こす Raf-1 に対する siRNA（siRaf-1, 21 bp, MW: 13300) を共搭載させた PEG-PCL-Peptide ミセルを調製 し，その脳腫瘍同所移植ラットにおける治療効果を 評価した。

Figure $5(\mathrm{~A})$ 及び Table 2 に，C6 ラットグリオー マ細胞を同所移植したラットに，移植日より 7 日間 naked siRaf-1, siRaf-1-loaded PEG-PCL-Peptide, CPT/Control siRNA (siControl)-loaded PEG-PCLPeptide, CPT/siRaf-1-loaded PEG-PCL-Peptide を それぞれ経鼻投与した際の生存日数を示す。Table 2 より, 未処置群, naked siRaf-1 群の平均生存日 数は 16.6 日，18.4 日と短かったのに対し，siRaf-1loaded PEG-PCL-Peptide, CPT/siControl-loaded PEG-PCL-Peptide 群は，それぞれ20.4日，20.6日 と, 未処置群と比較して有意な生存日数の延長が認 められた。 さらに，CPT/siRaf-1-loaded PEG-PCLPeptide 群では, 平均生存日数は 28.4 日となり, 他 群と比べ有意な生存期間の延長を示した. Figure 5 (B) に, C6 細胞移植 2 週間後の未処置群と各投与 群の脳切片を示す. 結果より, siRaf-1-loaded PEGPCL-Peptide, 及び CPT/siControl-loaded PEGPCL-Peptide 群では, 未処置群, naked siRaf-1 群 に比べて腫瘍組織の縮小が観察された。ささに, CPT/siRaf-1-loaded PEG-PCL-Peptide 群では, 顕
著な腫瘍組織の浸潤抑制効果がみられた。よつて, PEG-PCL-Peptide は, siRNA の Nose-to-Brain デ リバリーによる CNS 疾患治療に有効なキャリアで あることが示された。ささらに，疎水性低分子薬物と 共搭載できることから，薬物と核酸医薬による相 加・相乗効果を発揮する可能性が示された.

\section{おわりに}

本研究により, 経鼻投与と細胞透過性ナノキャリ

ア (PEG-PCL-Peptide) を組み合わせた Nose-toBrain DDS を用いることで，物質移行が非常に難 しいとされる脳へ効率的に薬物や核酸を送達できる ことを明らかとした．本研究成果は，根治療法のな いCNS 疾患に対する画期的な薬物療法の開発に貢 献するものと期待される．今後，本 DDS 技術を用 いて様々な薬物・バイオ医薬による CNS 疾患に対 する有効性を評価していく予定である。また, Nose-to-Brain 研究に関して, 移行経路や脳移行後 の脳内における動態に関していまだ不明な点が残さ れている.さらにこれまで，げっ歯類での疾患モデ ルに対する薬理効果を示す報告は多いものの，その 薬物動態や送達機構，及びヒトへの応用におけるボ トルネックについての議論は非常に少ない. 13) 今後 は，更なる研究発展のために，Nose-to-Brain を介 した移行機構を解明し，ヒトへ応用可能な Nose-toBrain DDS・製剤の開発につなげていきたい.

\section{謝辞本研究を遂行するにあたり，終始懇切丁} 寧なご指導, ご鞭撻を賜りました東京薬科大学薬学 部 岡田弘晃名誉教授, 高島由季准教授に心より感 謝申し上げます。また，研究の遂行においてご助 言，ご協力頂きました，名古屋市立大学薬学部尾関 哲也教授, 日本大学薬学部鈴木豊史教授, 帝京大学 薬学部出口芳春教授, 黄倉 崇教授, 長浜バイオ大 学福田常彦教授にこの場をお借りして深謝致しま す。本研究は, 東京薬科大学薬学部製剂設計学教室 にて実施され, 瀬田康生教授, 茨木ひさ子助手のご 協力, 並びに教室卒業生, 修了生である, 滝 洋幸 修士, 鈴木翔平学士, 森崎一貴学士, 秋山史成学 士，柿崎詩野学士，金子真未学士の多大な努力によ り得られた研究成果となります。この場をお借りし て心より感謝申し上げます。最後に，本研究は，科 学研究費補助金を始めとする様々な助成金により行 われました。ここに御礼申し上げます。 
利益相反＼cjkstart開示すべき利益相反はない。

\section{REFERENCES}

1) Armulik A., Genové G., Mäe M., Nisancioglu M. H., Wallgard E., Niaudet C., He L., Norlin J., Lindblom P., Strittmatter K., Johansson B. R., Betsholtz C., Nature, 468, 557561 (2010).

2) Pardridge W. M., Drug Discov. Today, 6, 381-383 (2001).

3) Illum L., Eur. J. Pharm. Sci., 11, 1-18 (2000) .

4) Frey W. H., Drug Deliv. Technol., 2, 46-49 (2002).

5) Lochhead J. J., Thorne G., Adv. Drug Deliv. Rev., 64, 614-628 (2012).

6) Djupesland P. G., Messina J. C., Mahmoud R. A., Ther. Deliv., 5, 709-733 (2014).
7) Kanazawa T., Med. Devices (Auckl) , 8, 57-64 (2015) .

8) Tanaka K., Kanazawa T., Shibata Y., Suda Y., Fukuda T., Takashima Y., Okada H., Int. J. Pharm., 396, 229-238 (2010).

9) Kanazawa T., Morisaki K., Suzuki S., Takashima Y., Mol. Pharm., 11, 1471-1478 (2014) .

10) Kanazawa T., Taki H., Tanaka K., Takashima Y., Okada H., Pharm. Res., 28, 2130-2139 (2011).

11) Kanazawa T., Akiyama F., Kakizaki S., Takashima Y., Seta Y., Biomaterials, 34, 9220-9226 (2013).

12) in 't Veen J. P., van den Berg M. P., Romeijn S. G., Verhoef J. C., Merkus F. W., Eur. J. Pharm. Biopharm., 61, 27-31 (2005).

13) Kozlovskaya L., Abou-Kaoud M., Stepensky D., J. Control. Release, 10, 133-140 (2014). 